\title{
The Role of Public and Private Actors and Means in Implementing the SDGs: Reclaiming the Public Policy Space for Sustainable Development and Human Rights
}

\author{
Jens Martens
}

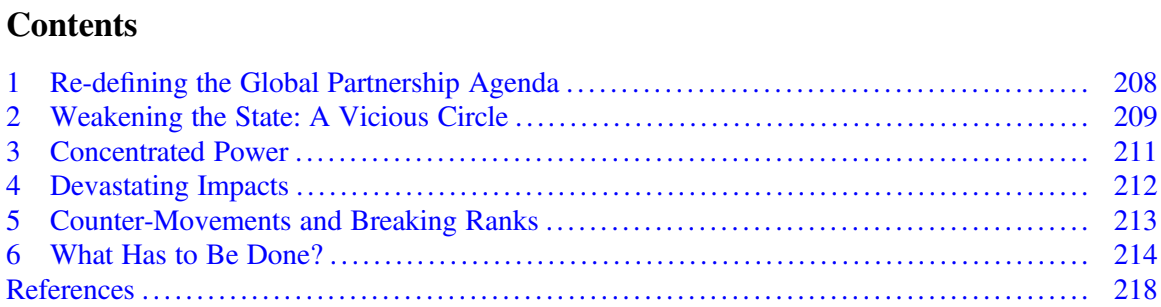

\begin{abstract}
In the 2030 Agenda governments committed to a revitalized Global Partnership between States and declared that public finance has to play a vital role in achieving the Sustainable Development Goals (SDGs). But in recent decades, the combination of neoliberal ideology, corporate lobbying, business-friendly fiscal policies, tax avoidance and tax evasion has led to a massive weakening of the public sector and its ability to provide essential goods and services and to fulfill its human rights obligations. The same corporate strategies and fiscal and regulatory policies that led to this weakening have enabled an unprecedented accumulation of individual wealth and increasing market concentration. The proponents of privatization and public-private partnerships (PPPs) use these trends to present the private sector as the most efficient way to provide the necessary means for implementing the SDGs. But many studies and experiences by affected communities have shown that privatization and PPPs involve disproportionate risks and costs for the public sector and can
\end{abstract}

This article is based on the findings of the international civil society report Spotlight on Sustainable Development 2017. An earlier version was published as introductory chapter of this report on behalf of the Civil Society Reflection Group on the 2030 Agenda for Sustainable Development.

\section{J. Martens ( $ه)$}

Global Policy Forum, Bonn, Germany

e-mail: jensmartens@globalpolicy.org 
even exacerbate inequalities, decrease equitable access to essential services and jeopardize the fulfilment of human rights. Therefore, it is high time to counter these trends, reclaim public policy space and take bold measures to strengthen public finance, rethink PPPs and weaken the grip of corporate power on people's lives.

\section{Re-defining the Global Partnership Agenda}

When governments negotiated the 2030 Agenda in 2015 there were hard fights about the nature of a global partnership. While the G77 and its members from the global South emphasized the need for a revitalized global partnership among governments, the USA, the EU and their partners from the global North pushed for all kinds of partnerships between public and private actors to implement the Agenda and its goals. The latter followed the line of reasoning of the High-Level Panel of Eminent Persons on the post-2015 Development Agenda that stated in its final report in May 2013:

We live in an age when global problems can best be solved by thousands, even millions, of people working together. These partnerships can guide the way to meeting targets and ensuring that programmes are effective on the ground. [...] These partnerships are powerful because each partner comes to the table with direct knowledge and strong evidence, based on thorough research. This enables them to innovate, to advocate convincingly for good policies, and thus to secure funding. ${ }^{1}$

In the context of the 2030 Agenda, the difference between partnership and partnerships is not just semantic sophistry but reflects two fundamentally different views of the role of the State: on the one hand as duty-bearer, particularly with respect to human rights, and as central provider of public goods and services, on the other hand as moderator and facilitator of actions of various public and private 'stakeholders'.

At the end of negotiations on the 2030 Agenda, governments agreed on a clearly graduated compromise: they fully committed to a revitalized Global Partnership at the governmental level and declared that public finance "will play a vital role in providing essential services and public goods and in catalysing other sources of finance."2 But they also acknowledged the role of the "diverse private sector, ranging from micro-enterprises to cooperatives to multinationals, and that of civil society organizations and philanthropic organizations in the implementation of the new Agenda.",3

In SDG 17 on means of implementation, governments included two targets under the subheading "Multi-stakeholder partnerships", but even there they first committed

\footnotetext{
${ }^{1}$ High-Level Panel of Eminent Persons on the post-2015 Development Agenda (2013), p. 22.

${ }^{2} \mathrm{UN}$ (2015b), para. 41.

${ }^{3}$ Ibid.
} 
to enhance the Global Partnership for Sustainable Development, only "complemented by multi-stakeholder partnerships" (target 17.16) and qualified the relevance of public-private partnerships by embedding them between public and civil society partnerships (target 17.17).

The embrace of the private sector and public-private partnerships became more visible in the outcome document of the Third International Conference on Financing for Development from July 2015, the Addis Ababa Action Agenda (AAAA). ${ }^{4}$ This de facto funding programme for the SDGs devotes a separate chapter to the important role of private business and finance, and it contains 11 paragraphs that promote, welcome or encourage the use of multi-stakeholder or public-private partnerships. ${ }^{5}$

The trend towards partnerships with the private sector is based on a simple assumption: global problems are too big and the public sector is too weak to solve them alone.

\section{Weakening the State: A Vicious Circle}

The trend towards privatization and the promotion of public-private partnerships (PPPs) of various kinds are not at all new. The world faced a first wave of deregulation and privatization in the 1980s and 1990s, promoted by neoliberal policies of Western governments, advanced by the transition from centrally planned to market economies in Eastern Europe and the former Soviet Union, and imposed by Structural Adjustment Programmes of IMF and World Bank in highly indebted countries of the global South.

In the aftermath of the global financial crisis 2007-2008 the discourse around privatization and PPPs has gained new momentum, particularly shaped by corporate think tanks and international financial institutions (IFIs). At a time when governments seem unable and unwilling to resolve pressing challenges, private actors are positioning themselves as an alternative solution, more flexible, efficient and un-bureaucratic than governments.

A telling example of this strategy is the report of the World Economic Forum (WEF) on the future of global governance, "Global Redesign". 6 The report postulates that a globalized world is best managed by a coalition of multinational corporations, governments (including through the UN system) and select civil society organizations (CSOs). It argues that governments no longer are "the overwhelmingly dominant actors on the world stage" " and that "the time has come for a new stakeholder paradigm of international governance". 8 The World Economic

\footnotetext{
${ }^{4} \mathrm{UN}(2015 \mathrm{a})$.

${ }^{5}$ Ibid., paras. 10, 42, 46, 48, 49, 76, 77, 115, 117, 120 and 123.

${ }^{6}$ World Economic Forum (2010).

${ }^{7}$ Ibid., p. 8 .

${ }^{8}$ Ibid., p. 9 .
} 
Forum vision includes a "public-private" $\mathrm{UN}$, in which certain specialized agencies would operate under joint State and non-State governance systems, such as the Food and Agriculture Organization (FAO) through a "Global Food, Agriculture and Nutrition Redesign Initiative". ${ }^{9}$ This model also assumes that some issues would be taken off the agenda of the UN system to be addressed by "plurilateral, often multi-stakeholder, coalitions of the willing and able". ${ }^{10}$

The IFIs, led by the World Bank, argued in a similar way in the discussions about the 2030 Agenda and the implementation of the SDGs. They called for a "paradigm shift on how development will be financed [...] to unlock the resources needed to achieve the SDGs." ${ }^{11}$ In their view, the global community needs to move the discussion from "billions" in ODA to "trillions" in investments of all kinds, to meet the investment needs of the SDGs. While they admit that the majority of development spending happens at the national level in the form of public resources, they stress that the largest potential for additional funds is from private sector business, finance and investment. "This is the trajectory from billions to trillions, which each country and the global community must support together to finance and achieve the transformative vision of the SDGs." ${ }^{12}$

But why is it apparently a matter of fact that the public sector is too weak to meet the challenges of the 2030 Agenda? Why are public coffers empty? In fact, the lack of capacity and financial resources is not an inevitable phenomenon but has been caused by deliberate political decisions. To give just one example, over the past three decades corporate income tax rates have declined in both countries of the global North and South by $15-20 \% .{ }^{13}$ Hundreds of billions of US dollars are lost every year through corporate tax incentives and various forms of tax avoidance. Through their business-friendly fiscal policies and the lack of effective global tax cooperation, governments have weakened their revenue base substantially. This has been driven not least by corporate lobbying. A recent analysis by Oxfam America estimates that between 2009 and 2015, the USA's 50 largest companies spent approximately US\$ 2.5 billion on lobbying, with approximately US $\$ 352$ million lobbying on tax issues. In the same period, they received over US\$ 423 billion in tax breaks. ${ }^{14}$

Widespread tax evasion and avoidance by transnational corporations and wealthy individuals make things even worse. It further decreases public revenues and exacerbates inequalities, as tax evasion seems to rise sharply with wealth. According to recent estimates by researchers in Norway, Sweden and Denmark, on average about 3\% of personal taxes are evaded in Scandinavia, but this figure rises to about $30 \%$ in the top $0.01 \%$ of the wealth distribution, a group that includes households

\footnotetext{
${ }^{9}$ Ibid., p. 367.

${ }^{10}$ Ibid., p. 8.

${ }^{11}$ World Bank et al. (2015), p. 2.

${ }^{12}$ Ibid., p. 1.

${ }^{13}$ Crivelli et al. (2015).

${ }^{14}$ Oxfam America (2017), p. 2.
} 
with more than US\$ 40 million in net wealth. ${ }^{15}$ The authors conclude: "Taking tax evasion into account increases the rise in inequality."16

What we see is a vicious circle of weakening the State: the combination of neoliberal ideology, corporate lobbying, business-friendly fiscal policies, tax avoidance and tax evasion has led to the massive weakening of the public sector and its ability to provide essential goods and services, as described in the report Spotlight on Sustainable Development 2017, inter alia, in its analyses on food security and sustainable agriculture (SDG 2), health (SDG 3), education (SDG 4), water (SDG 6), transport and housing (SDG 11). ${ }^{17}$ These failures have been used by the proponents of privatization and PPPs to present the private sector as the better alternative and to demand its further strengthening. This in turn further weakened the public sector-and so on....

In parallel, the same corporate strategies and fiscal and regulatory policies that led to the weakening of the public sector enabled an unprecedented accumulation of individual wealth and increasing market concentration, often at the expense of small and medium-sized enterprises.

\section{Concentrated Power}

The globalization of the world economy and the waves of deregulation and privatization have facilitated the emergence and increased the power of large transnational corporations (TNCs) and financial conglomerates. Companies with activities in dozens of countries and billion-dollar turnovers have acquired both great influence on the global economic system and significant political clout.

According to various statistics of the largest national economies, transnational corporations, banks and asset management firms, among the 50 largest global economic entities are more private corporations than countries. ${ }^{18}$ The assets under management by the world's largest asset management company BlackRock are US\$ 5.12 trillion (end of 2016), ${ }^{19}$ thus higher than the GDP of Japan or Germany.

Increasing market concentration has put greater power in the hands of a small number of corporations. An investigation of the relationships between 43,000 transnational corporations has identified a small group of companies, mainly in the financial industry, with disproportionate power over the global economy. According to the study by the Swiss Federal Institute of Technology in Zurich, "transnational corporations form a giant bow-tie structure and [...] a large portion of control flows

\footnotetext{
${ }^{15}$ Alstadsæter et al. (2017), p. 1.

${ }^{16}$ Ibid.

${ }^{17}$ Civil Society Reflection Group on the 2030 Agenda for Sustainable Development (2017).

${ }^{18}$ www.willistowerswatson.com/en/insights/2016/10/The-worlds-500-largest-asset-managersyear-end-2015.

${ }^{19}$ www.blackrock.com/de/privatanleger/uber-blackrock.
} 
to a small tightly-knit core of financial institutions. ${ }^{20}$ At the centre of the bow tie, a core of 147 companies control $40 \%$ of the network's wealth, while just 737 companies control $80 \%$.

Large institutional investors such as pension funds, insurance funds and sovereign wealth funds are also the drivers of a new generation of PPPs in infrastructure, forcing governments to offer 'bankable' projects that meet the needs of these investors rather than the needs and rights of the affected population. ${ }^{21}$

Particularly alarming for the implementation of SDG 2 on food security and sustainable agriculture are the announced mega-mergers in the food and agriculture sector, especially the acquisition of Syngenta by China National Chemical Corporation (ChemChina), the merger of Dow Chemical and DuPont and the takeover of Monsanto by Bayer. If all of these mergers are allowed, the new corporate giants will together control at least $60 \%$ of global commercial seed sales and $71 \%$ of global pesticide sales. $^{22}$

The growth and concentration of corporate power also includes private military and security companies (PMSCs). A 2011 study estimated the number of employees in this sector to be between 19.5 and 22.5 million, a number which exceeds the number of police officers worldwide. ${ }^{23}$ The growth of this sector directly affects the implementation of SDG 16, as PMSCs can play a critical role in enabling violent conflicts by outsourcing political, economic and human costs.

\section{Devastating Impacts}

Privatization, PPPs and the rise of corporate power affect all areas and goals of the 2030 Agenda. One obvious example is the mushrooming of private, fee-charging, profit-making schools in Africa and Asia, with the particular case of Bridge International Academies, which operates 500 nursery and primary schools in Kenya, Uganda, Nigeria, Liberia and India. ${ }^{24}$

Detrimental corporate influence occurs in the energy sector with the still dominant role of coal and fossil fuel industries, undermining effective measures against climate change and the transformation towards sustainable energy systems. The extractive industries play a similar role, particularly with the rush to mine in the deep sea representing its newest frontier and perhaps the biggest threat to the world's oceans. Biodiversity and terrestrial ecosystems are equally threatened by the commodification of the values and 'services' provided by these industries, and by market-based conservation mechanisms. They risk marginalizing the actors that

\footnotetext{
${ }^{20}$ Vitali et al. (2011).

${ }^{21}$ Boys (2017), p. 93f.

${ }^{22}$ ETC Group (2017).

${ }^{23}$ Florquin (2011).

${ }^{24}$ Wulf (2017), p. 57.
} 
play a central role in biodiversity conservation: indigenous peoples and local communities.

Studies by scholars, CSOs and trade unions like Public Services International (PSI) have shown that the privatization of public infrastructure and services and various forms of PPPs involve disproportionate risks for the affected people and costs for the public sector. They can even exacerbate inequalities, decrease equitable access to essential services, and thus jeopardize the fulfilment of human rights, particularly the rights of women.

Even evaluations done by the World Bank, the IMF and the European Investment Bank (EIB) — the organizations normally promoting PPPs—-have found many cases where PPPs did not yield the expected outcomes. ${ }^{25}$ Some of the findings of various studies on the risks and costs of PPPs can be summarized as follows:

- only very few countries have sufficient capacity to implement infrastructure PPPs;

- the cost of financing is higher for PPPs than for public sector works, as governments usually borrow at a lower rate than the private sector;

- potential short-term fiscal profits from large-scale PPPs are not always sufficient to offset the long-term additional costs arising from contract renegotiations;

- government liabilities for PPPs appear 'off-budget', so governments have the illusion that they have more fiscal space than they actually do.

Addressing the role of the G20 in a recent paper on infrastructure investment and PPPs, Nancy Alexander of the Heinrich Böll Foundation summarizes:

The scale of the infrastructure and PPP initiative championed by the G20's national and multilateral banks could privatize gains and socialize losses on a massive scale. The G20 should take steps to ensure that this scenario does not unfold. ${ }^{26}$

\section{Counter-Movements and Breaking Ranks}

Responding to the experiences and testimonies from the ground about the devastating impacts of privatization and PPPs, counter-movements emerged in many parts of the world. Over the past 15 years there has been a significant rise in the number of communities that have taken privatized services back into public hands-a phenomenon called "remunicipalization". ${ }^{27}$ Remunicipalization refers particularly to the return of water supply and sanitation services to public service delivery. Between March 2000 and March 2015 researchers documented 235 cases of water remunicipalization in 37 countries, affecting more than 100 million people.

\footnotetext{
${ }^{25}$ See references e.g., in Jomo et al. (2016) and Alexander (2016).

${ }^{26} \mathrm{https} / / /$ us.boell.org/2016/12/15/infrastructure-investment-and-public-private-partnerships.

${ }^{27}$ Kishimoto (2016).
} 
Furthermore, some pioneering companies are already on the path towards-at least environmentally - sustainable development solutions, for instance in the area of renewable energies. The private sector is in no way a monolithic bloc. Firms in the social and solidarity economy, social impact investors and small and medium-sized businesses are already making a positive difference, challenging the proponents of global techno-fix solutions and the dinosaurs of the fossil fuel lobby.

Even the firm opposition to international corporate regulation in the field of business and human rights by those pretending to represent business interests is showing cracks. A survey by The Economist Intelligence Unit revealed that a significant proportion of business representatives are now in favour of an international legal instrument to regulate corporate activities. The report concludes that:

(...) although the reaction by most businesses has been negative, questioning not only the desirability but the efficacy and feasibility of such an instrument, $20 \%$ of respondents to our survey said that a binding international treaty would help them with their responsibilities to respect human rights. ${ }^{28}$

\section{What Has to Be Done?}

To be sure, the business sector certainly has an important role to play in the implementation process of the 2030 Agenda, as sustainable development will require large-scale changes in business practices. However, acknowledging corporations' role should not mean promoting the accumulation of wealth and economic power, giving them undue influence on policy-making and ignoring their responsibility in creating and exacerbating many of the problems that the 2030 Agenda is supposed to tackle.

Instead of further promoting the misleading discourse of 'multi-stakeholderism' and partnerships between inherently unequal partners a fundamental change of course is necessary. In order to achieve the SDGs and to turn the vision of the transformation of our world, as proclaimed in the title of the 2030 Agenda, into reality, we have to reclaim the public (policy) space. This includes, inter alia, the following steps:

\section{Strengthening Public Finance at All Levels}

Widening public policy space requires, among other things, the necessary adjustments in fiscal policies. In other words, governments have to formulate Sustainable Development Budgets in order to implement the Sustainable Development Goals. They can generally approach the issue from both the revenue (tax policy) and the expenditure (budget policy) angle. They can pursue proactive tax policies to achieve

\footnotetext{
${ }^{28}$ The Economist Intelligence Unit (2015), p. 23.
} 
environmental and social policy goals and simultaneously fulfill their human rights obligations. This includes, for example, the taxation of the extraction and consumption of non-renewable resources, and forms of progressive taxation that are sensitive to the welfare of poor and low-income people (e.g., by taxing consumption of luxuries). Fiscal policy space can be further broadened by the elimination of corporate tax incentives (including tax holidays in export processing zones), and the phasing out of harmful subsidies. If the priorities are properly defined, fiscal policies can become a powerful instrument to reduce social inequalities, eliminate discrimination and promote the transition to sustainable production and consumption patterns.

The necessary reforms should not be limited to the national level. The strengthening of public finance is necessary at all levels, from the development of municipal fiscal systems and sufficient financial support for local authorities, to the provision of predictable and reliable funding to the UN system at a level sufficient to enable it to fulfill its mandates. In particular, governments should reverse the trend towards voluntary, non-core and earmarked contributions and the increasing reliance on philanthropic funding. A basic prerequisite for the strengthening of national fiscal systems is the strengthening of global tax cooperation to counter harmful tax competition and various schemes of tax avoidance and evasion.

\section{Strengthening Public Policies Instead of Investors' Rights}

Corporate lobby groups have been advocating forcefully against 'overregulation', and for the continuation of exactly those trade, investment and financial rules that have destabilized the global economy and exacerbated inequalities in both the global North and the global South. Furthermore, a new generation of free trade and investment agreements risks a further reduction in the policy space of governments to implement sound social, environmental and developmental policies. These agreements will add to the power of investors and big corporations and, by the same token, weaken the role of the State and its ability to promote human rights and sustainability. Governments should fundamentally rethink their approach towards trade and investment liberalization and take into account the demands of civil society organizations, trade unions, indigenous peoples, human rights experts and many others, to place human rights and the principles of sustainable development at the core of all trade and investment agreements. This includes the ability to implement active industrial policies to enable the rise of a strong domestic enterprise sector in countries of the global South. 


\section{Rethinking PPPs: Searching for Alternatives}

Business actors and corporate think tanks like the WEF have been steadily promoting PPPs as the primary model to fill the global funding gap in infrastructure investment. Many governments have followed their advice. But as mentioned above, many studies, including those by mainstream think tanks, prove that PPPs can involve enormous risks and costs to the public sector, exacerbate inequalities and decrease equitable access to essential services. Governments should take these findings and concerns into account, rethink their approach towards private sector participation in infrastructure investment, and explore alternative means of public infrastructure financing. This may include revenues from property taxes, service charges and user fees, in compliance with human rights standards, funding by public banks, the issuance of public (including municipal) bonds, ways to cross-subsidize different public services, and, in certain cases, ODA funding.

\section{Creating Binding Rules on Business and Human Rights and UN-Business Interactions}

Experience shows that corporate social responsibility (CSR) initiatives and voluntary guidelines, such as the UN Guiding Principles on Business and Human Rights (UNGP) have failed to hold corporations accountable. Various governments, CSOs and human rights experts have concluded that there is a need for a legally binding instrument (or 'treaty') to regulate, in international human rights law, the activities of transnational corporations and other business enterprises. The Human Rights Council took a milestone decision by establishing an intergovernmental working group to elaborate such an instrument. Governments and CSOs should take this 'treaty process' seriously and engage actively in it. This process offers the historic opportunity for governments to demonstrate that they put human rights over the interests of big business. This will be a critical prerequisite for implementing the 2030 Agenda, not least the goal to ensure sustainable consumption and production patterns.

Similarly, the UN should develop a regulatory framework for UN-business interactions (including the various forms of partnerships). It should set minimum standards for the participation of the UN in global partnerships and for the shape and composition of UN initiatives involving the private sector. These standards should prevent undue corporate influence on UN policies and prevent companies that violate internationally agreed environmental, social and human rights standards or otherwise violate UN principles (via corruption, breaking UN sanctions, lobbying against UN global agreements, evading taxes, etc.) from participation in UN events and from eligibility for UN procurement. 
One essential element of such a framework should be a mandatory conflict of interest and public disclosure policy for all interactions with non-State actors, with additional requirements specific to the respective UN funds, programmes and specialized agencies. Furthermore, such a regulatory framework should distinguish clearly between corporate actors and CSOs and refrain from treating fundamentally different actors as equals.

\section{Dismantle Corporate Power and 'Too Big to Fail' Entities}

The deregulation and privatization policies of the last decades have enabled increasing market concentration and the accumulation of wealth and economic power in the hands of a relatively small number of corporations and ultra-rich individuals. Existing competition and anti-trust laws have been obviously too weak to prevent mega-mergers, as recently have taken place in the agribusiness sector, and to curtail the massive growth of financial conglomerates with disproportionate influence on the global economy - and thereby directly or indirectly on the implementation of the SDGs.

In order to strengthen the role of the State and democratic decision-making processes on issues of common interest in societies, as well as ensure the provision of public services governments have to take effective measures to dismantle corporate power and prevent the further existence of corporate 'too big to fail' entities, particularly in the global shadow banking system. They should strengthen national and regional anti-trust laws, cartel offices and competition regulators. And they have to improve anti-trust policies, cooperation and legal frameworks at the global level under the auspices of the UN. This could include the development of a UN Convention on Competition, as proposed by the ETC Group.

\section{Changing the Mindset: Reclaiming the Public Space}

The measures listed above are indispensable to counteract the growing, non-monitored influence of corporate interests in the implementation of the 2030 Agenda and beyond. But these measures are not ends in themselves. There is a need to reconsider the current mainstream approach based on voluntary governance and partnerships among diverse 'stakeholders'. It is important to re-establish a clear distinction between those who should regulate and the party to be regulated and to reject any discourse that obfuscates the fact that corporations have a fundamentally different primary interest from that of governments, UN agencies, CSOs, and social movements: corporations' primary interest—enshrined in their fiduciary duty-is to 
satisfy the interests of their owners, creditors and shareholders. The stakeholder discourse blurs this important distinction between the different actors.

Certainly, meaningful engagement with all sectors of society is a pre-requisite for democratic decision-making as well as providing invaluable and essential expertise in the identification of problems and solutions. Governments and the UN should continue to develop their commitments and capacities in this area without relying on a one-size-fits-all approach. They should develop models which will allow all actors in society to make contributions and to protect against the influence of vested interests. Rather than continuing to 'innovate' through 'outsourcing' tasks to piecemeal partnerships with undemocratic decision-making structures, it is time for civil society to reclaim the public space-and for governments to put in place the necessary regulatory and global governance framework.

In the preamble to the 2030 Agenda governments described the "enormous disparities of opportunity, wealth and power" as one of the immense challenges (i.e., obstacles) to sustainable development. ${ }^{29}$ The SDGs can only be achieved when governments take active political steps to overcome these disparities.

\section{References}

Alexander N (2016) Infrastructure investment and Public Private Partnerships. Washington, D.C., Heinrich Böll Stiftung North America (G20 Themes \#5). https://us.boell.org/sites/default/files/ uploads/2016/12/https__www.boell.de_sites_default_files_uploads_2016_12_g20-themes5infrastructure-investment-ppp_0.pdf. Accessed 15 Jan 2018

Alstadsæter A, Johannesen N, Zucman G (2017) Tax evasion and inequality. Norwegian University of Life Sciences/University of Copenhagen/UC Berkeley and NBER. http://gabriel-zucman.eu/ files/AJZ2017.pdf. Accessed 15 Jan 2018

Boys D (2017) The new generation of PPPs in infrastructure - meeting the needs of institutional investors. In: Civil Society Reflection Group on the 2030 Agenda for Sustainable Development (2017), pp 93-94

Civil Society Reflection Group on the 2030 Agenda for Sustainable Development (2017) Spotlight on Sustainable Development 2017. Reclaiming policies for the public. Privatization, partnerships, corporate capture and their impact on sustainability and inequality - assessments and alternatives. Beirut/Bonn/Ferney-Voltaire/Montevideo/New York/Penang/Rome/Suva. www. 2030spotlight.org. Accessed 15 Jan 2018

Crivelli E, de Mooij RA, Keen M (2015) Base erosion, profit shifting and developing countries. IMF, Washington, D.C. www.sbs.ox.ac.uk/sites/default/files/Business_Taxation/Docs/Publica tions/Working_Papers/Series_15/WP1509.pdf. Accessed 15 Jan 2018

ETC Group (2017) Agribusiness mega-mergers expose need for UN Competition Convention. In: Civil Society Reflection Group on the 2030 Agenda for Sustainable Development (2017), pp 43-45

${ }^{29} \mathrm{UN}(2015$ b), para. 14. 
Florquin N (2011) A booming business: private security and small arms. In: Small Arms Survey (2011), pp 101-133

High-Level Panel of Eminent Persons on the post-2015 Development Agenda (2013) The Report of the High-level Panel of Eminent Persons on the Post-2015 Development Agenda. New York. http://report.post2015hlp.org/digital-report-chapter-4.html. Accessed 15 Jan 2018

Jomo KS, Chowdhury A, Sharma K, Platz D (2016) Public-Private Partnerships and the 2030 Agenda for Sustainable Development: fit for purpose? New York, UN Department of Economic \& Social Affairs (DESA Working Paper No. 148, ST/ESA/2016/DWP/148). https:// sustainabledevelopment.un.org/content/documents/2288desaworkingpaper148.pdf. Accessed 15 Jan 2018

Kishimoto S (2016) Remunicipalization: a practical guide for communities and policy makers. Transnational Institute, Amsterdam. www.blueplanetproject.net/wordpress/wp-content/ uploads/PublicWaterForAll-Mar14-Remun.pdf. Accessed 15 Jan 2018

Oxfam America (2017) Rigged reform: US companies are dodging billions in taxes but proposed reforms will make things worse. Media briefing April 2017. www.oxfamamerica.org/static/ media/files/Rigged_Reform_FINAL.pdf. Accessed 15 Jan 2018

The Economist Intelligence Unit (2015) The road from principles to practice. Today's challenges for business in respecting human rights. Geneva/London/Frankfurt/Paris/Dubai. www. economistinsights.com/sites/default/files/EIU-URG\%20-\%20Challenges\%20for\%20business $\% 20$ in\%20respecting\%20human\%20rights\%20WEB_corrected\%20logos\%20and\%20UNWG \%20thx.pdf. Accessed 15 Jan 2018

UN (2015a) Addis Ababa Action Agenda of the Third International Conference on Financing for Development. New York. (UN Dok. A/RES/69/313). www.un.org/esa/ffd/wp-content/uploads/ 2015/08/AAAA_Outcome.pdf. Accessed 15 Jan 2018

UN (2015b) Transforming our world: the 2030 Agenda for Sustainable Development. New York (UN Doc. A/RES/70/1). https://sustainabledevelopment.un.org/post2015/ transformingourworld. Accessed 15 Jan 2018

Vitali S, Glattfelder JB, Battiston S (2011) The network of global corporate control. PLoS ONE 6:10. http://arxiv.org/PS_cache/arxiv/pdf/1107/1107.5728v2.pdf. Accessed 15 Jan 2018

World Bank et al (2015) From billions to trillions - transforming development finance. Washington, D.C. http://siteresources.worldbank.org/DEVCOMMINT/Documentation/23659446/DC20150002(E)FinancingforDevelopment.pdf. Accessed 15 Jan 2018

World Economic Forum (2010) Everybody's business: strengthening international cooperation in a more interdependent world - report of the global redesign initiative. Geneva. http://www3. weforum.org/docs/WEF_GRI_EverybodysBusiness_Report_2010.pdf. Accessed 15 Jan 2018

Wulf A (2017) Cashing in on SDG 4. In: Civil Society Reflection Group on the 2030 Agenda for Sustainable Development (2017), pp 57-63

Jens Martens is Executive Director of Global Policy Forum (New York/Bonn) and has been the director of Global Policy Forum Europe since its foundation in 2004. Since 2011 he has coordinated the international Civil Society Reflection Group on the 2030 Agenda for Sustainable Development. From 2003 to 2009 he was member (2006-2009 Co-Chair) of the Coordinating Committee of Social Watch, a global network of several hundred NGOs working on poverty eradication and social justice. He is also a member of the Advisory Board of the Development and Peace Foundation. Previously, he was a longstanding member of the Executive Board of the German NGO World Economy, Ecology and Development (WEED). Prior to joining the staff at WEED he worked as freelance author and advisor for several NGOs and Foundations, among others the German NGO Forum on Environment and Development, the Friedrich Ebert Foundation, and the Development and Peace Foundation. From 1991 to 1992 he worked as librarian and research fellow at the German Commission for UNESCO in Bonn. He has published many articles in journals, newspapers and 
handbooks, has written several books and studies on development policy and UN reform, and has been co-editor of three books on German UN policy, privatization and corporate accountability. Between 2003 and 2015 he was author of the German Reality of Aid Report published annually by Deutsche Welthungerhilfe and terre des hommes Germany. He studied economics and political sciences at the University Erlangen-Nürnberg and at the Free University of Berlin.

Open Access This chapter is licensed under the terms of the Creative Commons Attribution 4.0 International License (http://creativecommons.org/licenses/by/4.0/), which permits use, sharing, adaptation, distribution and reproduction in any medium or format, as long as you give appropriate credit to the original author(s) and the source, provide a link to the Creative Commons licence and indicate if changes were made.

The images or other third party material in this chapter are included in the chapter's Creative Commons licence, unless indicated otherwise in a credit line to the material. If material is not included in the chapter's Creative Commons licence and your intended use is not permitted by statutory regulation or exceeds the permitted use, you will need to obtain permission directly from the copyright holder. 